\title{
LENGTH-WEIGHT RELATIONS OF FISHES INHABITING A HYPERHALINE COASTAL LAGOON IN YUCATAN, MEXICO
}

\author{
Maria Eugenia VEGA-CENDEJAS ${ }^{1 *}$, Miguel A. PERALTA-MEIXUIERO², \\ and Mirella HERNÁNDEZ DE SANTILLANA ${ }^{1}$ \\ ${ }^{1}$ Centro de Investigación y de Estudios Avanzados del IPN - Unidad Mérida, Mérida, YUC, Mexico \\ ${ }^{2}$ Universidad de Ciencias y Artes de Chiapas, Tuxtla Gutiérrez, CHP, México
}

\begin{abstract}
Vega-Cendejas M.E., Peralta-Meixueiro M.A., Hernández de Santillana M. 2017. Length-weight relations of fishes inhabiting a hyperhaline coastal lagoon in Yucatan, Mexico. Acta Ichthyol. Piscat. 47 (4): $411-415$.
\end{abstract}

\begin{abstract}
Length-weight relations (LWR) were estimated for 45 fish species (27 families) from a tropical hyperhaline coastal lagoon and a protected biosphere reserve located in Yucatan Peninsula. The following species were studied: Elops saurus Linnaeus, 1766; Anchoa mitchilli (Valenciennes, 1848); Harengulajaguana Poey, 1865; Ariopsis felis (Linnaeus, 1766); Synodus foetens (Linnaeus, 1766); Opsanus beta (Goode et Bean, 1880); Mugil trichodon Poey, 1875; Menidia colei Hubbs, 1936; Menidia peninsulae (Goode et Bean, 1879); Atherinomorus stipes (Müller et Troschel, 1848); Strongylura notata (Poey, 1860); Chriodorus atherinoides Goode et Bean, 1882; Hyporhamphus meeki Banford et Collette, 1993; Fundulus grandissimus Hubbs, 1936; Lucania parva (Baird et Girard, 1855); Poecilia velifera (Regan, 1914); Cyprinodon artifrons Hubbs, 1936; Floridichthys polyommus Hubbs, 1936; Jordanella pulchra (Hubbs, 1936); Syngnathus makaxi Herald et Dawson, 1972; Prionotus tribulus Cuvier, 1829; Trachinotus falcatus (Linnaeus, 1758); Lutjanus griseus (Linnaeus, 1758); Diapterus auratus Ranzani, 1842; Diapterus rhombeus (Cuvier, 1829); Eucinostomus argenteus Baird et Girard, 1855; Eucinostomus gula (Quoy et Gaimard, 1824); Eucinostomus harengulus Goode et Bean, 1879; Eugerres plumieri (Cuvier, 1830); Gerres cinereus (Walbaum, 1792); Orthopristis chrysoptera (Linnaeus, 1766); Archosargus rhomboidalis (Linnaeus, 1758); Lagodon rhomboides (Linnaeus, 1766); Bairdiella chrysoura (Lacepède, 1802); Cynoscion nebulosus (Cuvier, 1830); Cynoscion arenarius Ginsburg, 1930; Micropogonias undulatus (Linnaeus, 1766); Menticirrhus littoralis (Holbrook, 1847); Menticirrhus americanus (Linnaeus, 1758); Menticirrhus saxatilis (Bloch et Schneider, 1801); Mayaheros urophthalmus (Günther, 1862); Gobiosoma robustum Ginsburg, 1933; Sphyraena barracuda (Edwards, 1771); Achirus lineatus (Linnaeus, 1758); Sphoeroides testudineus (Linnaeus, 1758). A total of 31011 specimens were collected using a beach seine and a trawl net from October 2004 through November 2005, and from August 2007 through October 2008. Dominant species were Floridichthys polyommus, Cyprinodon artifrons, Menidia colei, and Sphoeroides testudineus. Results indicated a negative (19 species) and positive (26 species) allometric growth. The present paper provides the first published LWRs estimations for Syngnathus makaxi and Eucinostomus harengulus, and a new maximum length record for Hyporhamphus meeki (20.9 cm standard length).
\end{abstract}

Keywords: Ría Lagartos Lagoon, L-W relation, hyperhaline ecosystem

Length-weight relations (LWR) are the key element in the research of biology, taxonomy, and ecology - the fisheries sciences, estimating the biomass of fish species from length observations. LWRs have been useful in determining fish weight based on its length (Xie et al. 2015), for development of fish population dynamics models (Kohler et al. 1995), in comparisons of fish species life histories between regions (Froese and Pauly 2017), ontogenetic allometric changes and estimations of isometric or allometric growth (Teixeira de Mello et al.
2006) in order to determine how the distribution of energy relates to axial growth or to biomass (Teixeira de Mello et al. 2009), and for evaluations of parasites effects (Teixeirade Mello and Eguren 2008). These estimations may differ between species of different regions, and among locations for the same species (Velázquez-Velázquez et al 2009). LWRs concerning fishes inhabiting protected tropical areas of south-eastern Mexico are very scarce (VegaCendejas et al. 1997). Thus, the aim of this study was to estimate the LWRs for 31011 specimens belonging 
to 45 fish species (representing 27 families) that inhabit a tropical coastal hyperhaline lagoon of Ría Lagartos, a Biosphere Reserve located in Yucatan Peninsula. The following species were studied: Elops saurus Linnaeus, 1766; Anchoa mitchilli (Valenciennes, 1848); Harengula jaguana Poey, 1865; Ariopsis felis (Linnaeus, 1766); Synodus foetens (Linnaeus, 1766); Opsanus beta (Goode et Bean, 1880); Mugil trichodon Poey, 1875; Menidia colei Hubbs, 1936; Menidia peninsulae (Goode et Bean, 1879); Atherinomorus stipes (Müller et Troschel, 1848); Strongylura notata (Poey, 1860); Chriodorus atherinoides Goode et Bean, 1882; Hyporhamphus meeki Banford et Collette, 1993; Fundulus grandissimus Hubbs, 1936; Lucania parva (Baird et Girard, 1855); Poecilia velifera (Regan, 1914); Cyprinodon artifrons Hubbs, 1936; Floridichthys polyommus Hubbs, 1936; Jordanella pulchra (Hubbs, 1936); Syngnathus makaxi Herald et Dawson, 1972; Prionotus tribulus Cuvier, 1829; Trachinotus falcatus (Linnaeus, 1758); Lutjanus griseus (Linnaeus, 1758); Diapterus auratus Ranzani, 1842; Diapterus rhombeus (Cuvier, 1829); Eucinostomus argenteus Baird et Girard, 1855; Eucinostomus gula (Quoy et Gaimard, 1824); Eucinostomus harengulus Goode et Bean, 1879; Eugerres plumieri (Cuvier, 1830); Gerres cinereus (Walbaum, 1792); Orthopristis chrysoptera (Linnaeus, 1766); Archosargus rhomboidalis (Linnaeus, 1758); Lagodon rhomboides (Linnaeus, 1766); Bairdiella chrysoura (Lacepède, 1802); Cynoscion nebulosus (Cuvier, 1830); Cynoscion arenarius Ginsburg, 1930; Micropogonias undulatus (Linnaeus, 1766); Menticirrhus littoralis (Holbrook, 1847); Menticirrhus americanus (Linnaeus, 1758); Menticirrhus saxatilis (Bloch et Schneider, 1801); Mayaheros urophthalmus (Günther, 1862); Gobiosoma robustum Ginsburg, 1933; Sphyraena barracuda (Edwards, 1771); Achirus lineatus (Linnaeus, 1758); Sphoeroides testudineus (Linnaeus, 1758). The majority of the collected specimens were juveniles, which may be explained by the critical nursery function of the lagoon, as well as fish species with high tolerant ranges to salinity (>50) and low oxygen levels $\left(2.0 \mathrm{mg} \cdot \mathrm{L}^{-1}\right)$ such as Floridichthys polyommus and Cyprinodon artifrons (see Vega-Cendejas and Hernandez de Santillana 2004, Peralta-Meixuero and Vega-Cendejas 2011).

Ría Lagartos Lagoon is located on the northeastern coast of Yucatan Peninsula, Mexico (21 $26^{\prime}-$ $\left.21^{\circ} 38^{\prime} \mathrm{N}, 87^{\circ} 30^{\prime}-88^{\circ} 15^{\prime} \mathrm{W}\right)$. It is a long $(80 \mathrm{~km})$, wide ( $25 \mathrm{~m}$ to $3.5 \mathrm{~km}$ ) coastal system, and has been considered a Biosphere Reserve for being a breeding and nesting area of pink flamingo Phoenicopterus ruber (see VegaCendejas and Hernández de Santillana (2004).

The sampling of the fish specimens was conducted bimonthly from October 2004 through November 2005, and from August 2007 through October 2008, using a beach seine (15-m long, 2.0-m high, and 2.5-cm mesh size), and a trawl net (3.5-m long, 0.33-cm mesh size). Depending on the season, the number of sampling stations along the lagoon ranged from 10 to 31 , because during the dry season the level of the water decreased drastically and was is not possible to operate the fishing gear.

Collected fishes were euthanized in an ice slurry, then preserved in formalin $(10 \%)$, and transported to the laboratory where they were identified, measured for standard length (SL) ( $\pm 0.1 \mathrm{~mm}$ precision), and weighed with an electronic scale $( \pm 0.01 \mathrm{~g}$ precision $)$. A representative sample of each species was deposited and catalogued in the Ichthyology Collection of the Centro de Investigación y de Estudios Avanzados del Instituto Politécnico Nacional (CINVESTAV), Merida (CINVNEC) with the reference number YUC-PEC.084.0999.

Parameters ( $a$ and $b$ ) of the LWR were estimated (using Statgraphics software; version 5.1) with a linear least squares regression using a $\log -\log$ scale

$$
W=a L^{b}
$$

where $W$ is the weight of the fish [g], $L$ is the standard length (SL) [cm], $a$ is the intercept, and $b$ is the regression coefficient (indicating isometric growth when equal to 3 ). Based on the slope $(b)$ of the relation between weight and length, one can check whether the growth of a fish is negative $(b<3)$, or positive allometric $(b>3)$ (Froese et al. 2011). Outliers were detected and eliminated using $\log -\log$ plots and 95\% confidence limits for $b$ (CI 95\% for $b$ ) were estimated by a Student's $t$-test (Froese 2006). Comparisons of maximum sizes recorded in previous studies were made using the records reported in FishBase (Froese and Pauly 2017). Scientific names of the fishes were verified following Eschmeyer et al. (2017).

A total of 31011 specimens were collected and they belonged to 45 species and represented 27 families. The ocellated killifish, Floridichthys polyommus, was the most abundant fish species (6886 specimens), followed by Yucatan pupfish, Cyprinodon artifrons, and golden silverside, Menidia colei (5868 and 4439, individuals respectively) (Table 1). The coefficient of determination $\left(r^{2}\right)$ ranged from 0.837 in Lucania parva to 0.993 in Eugerres plumieri. The parameter $b$ ranged from 2.582 in Menticirrhus americanus to 3.518 in Harengula jaguana. The value of $b$ for $H$. jaguana is like the one reported for this species at Celestun Lagoon (3550) (Vega-Cendejas et al. 2012). Differences in $b$ values among areas could be attributed to species morphology and environmental factors such as temperature, salinity, food (quantity, quality and size), sex, health, and developmental stage (Sparre and Venema 1992).

This study provides the first LWR estimation for Syngnathus makaxi and Eucinostomus harengulus (Table 1). We also present a new maximum length $\left(L_{\max }\right)$ record for Hyporhamphus meeki (20.9 cm SL). Results provided in this study are of importance for the management and functional knowledge of the hyperhaline ecosystems, which using ECOPATH modelling and trophic knowledge 


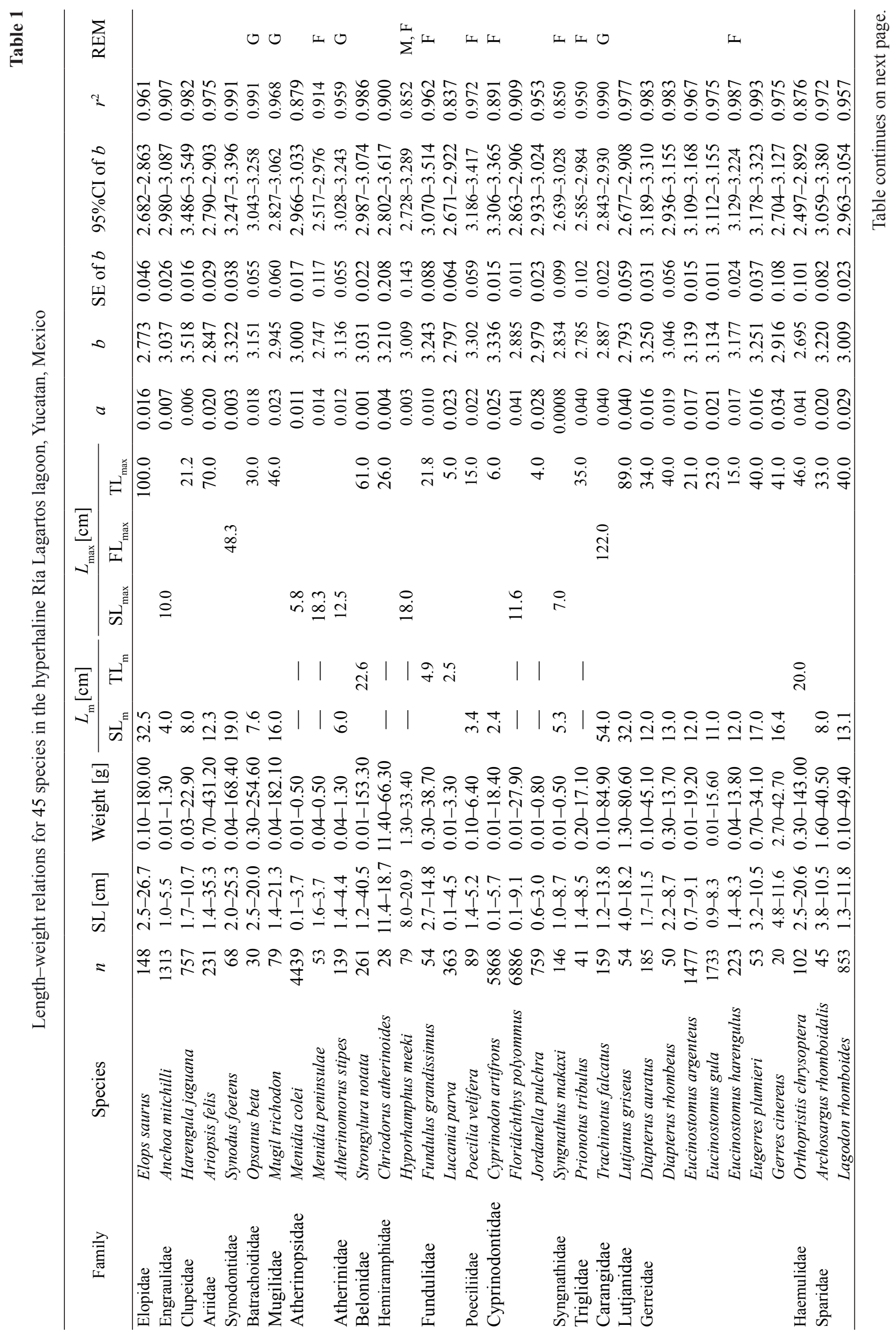




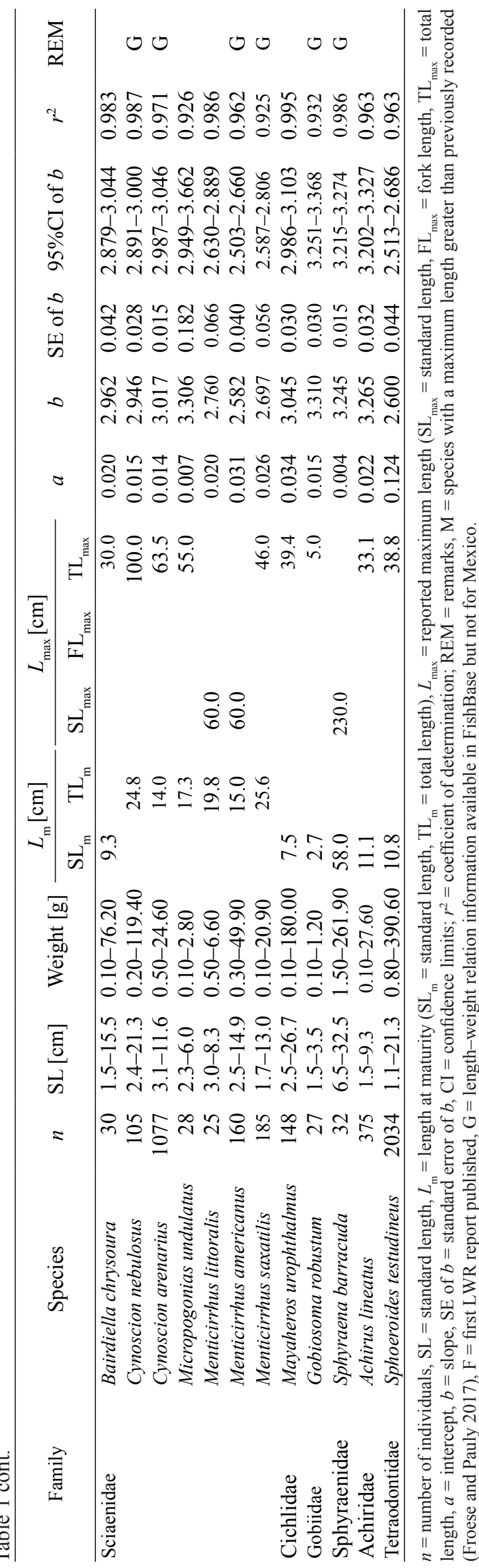

and population dynamics of the fish species, will allow evaluating the functionality of these unique ecosystems, with respects to its ecological dynamics.

\section{ACKNOWLEDGEMENTS}

The authors would like to thank to the Consejo Nacional de Ciencia y Tecnología, Mexico-Sistema de Investigación Regional "Justo Sierra" (CONACYTSISIERRA), which provided part of the financial support of this study and to René H. Kantún Palma, Director of the Ría Lagartos Biosphere Reserve for his help during the study. This study was also partly financed by a CONACYT doctoral scholarship granted to Miguel A. Peralta Meixuero. We are also very grateful to Alex Acosta, Victor Castillo, Grisel Díaz, Mónica Herrera, Judith Mazún, Ericka Canul, Oscar Navarrete, and Domingo Blanqueto, for field technical assistance and to Daniel Arceo for his laboratory support. We also thank the Centro de Investigación y de Estudios Avanzados del Instituto Politécnico Nacional, Mexico (CINVESTAV), for infrastructure support.

\section{REFERENCES}

Eschmeyer W.N., Fricke R., van der Laan R. (eds.) 2017. Catalog of fishes: Genera, species, references. California Academy of Sciences, San Francisco, USA. http://researcharchive.calacademy.org/research/ ichthyology/catalog/fishcatmain.asp [Accessed on 17 April 2017.]

Froese R. 2006. Cube law, condition factor and weightlength relationships: History, meta-analysis and recommendations. Journal of Applied Ichthyology 22 (4): 241-253. DOI: $10.1111 /$ j.1439-0426.2006.00805.x

Froese R., Pauly D. (eds.) 2017. FishBase. [Version 02/2017] www.fishbase.org

Froese R., Tsikliras A.C., Stergiou K.I. 2011. Editorial note on weight-length relations of fishes. Acta Ichthyologica et Piscatoria 41 (4): 261-263. DOI: 10.3750/AIP2011.41.4.01

Kohler N., Casey J., Turner P. 1995. Length-weight relationships for 13 species of sharks from the western North Atlantic. Fishery Bulletin 93 (2): 412-418.

Peralta-Meixueiro M.A., Vega-Cendejas M.E. 2011. Spatial and temporal structure of fish assemblages in a hyperhaline coastal system: Ría Lagartos, Mexico. Neotropical Ichthyology 9 (3): 673-682. DOI: $10.1590 /$ S1679-62252011005000033

Sparre P., Venema S.C. 1992. Introduction to tropical fish stock assessment. Part 1. Manual. FAO Fisheries Technical Paper No. 306/1. FAO, Rome.

Teixeira-de Mello F., Eguren G. 2008. Prevalence and intensity of black-spot disease in fish community from a subtropical stream (Santa Lucía River basin, Uruguay). Limnetica 27 (2): 251-258.

Teixeira de Mello F., Iglesias C., Borthagaray A.I., Mazzeo N., Vilches J., Larrea D., Ballabio R. 2006. Ontogenic allometric coefficient changes. Implication 
of diet shift and morphometric traits in Hoplias malabaricus (Bloch) (Characiforme, Erythrinidae). Journal of Fish Biology 69 (6): 1770-1778. DOI: $10.1111 / \mathrm{j} .1095-8649.2006 .01245 . \mathrm{x}$

Teixeira de Mello F., Vidal N., Gonzalez-Bergonzoni I., Iglesias C. 2009. Length-weight relationships of eight fish species from the lower section of the Uruguay River (Río Negro, Uruguay). Journal of Applied Ichthyology 25 (1): 128-129. DOI: $10.1111 / \mathrm{j} .1439-0426.2008 .01155 . \mathrm{x}$

Vega-Cendejas M.E., Hernández de Santillana M. 2004. Fish community structure and dynamics in a coastal hypersaline lagoon: Rio Lagartos, Yucatan, Mexico. Estuarine, Coastal and Shelf Science 60 (2): 285-299.

DOI: $10.1016 /$ j.ecss.2004.01.005

Vega-Cendejas M.E., de Santillana M.H., Arceo D. 2012. Length-weight relationships for selected fish species from a coastal lagoon influenced by freshwater seeps: Yucatan Peninsula, Mexico. Journal of Applied Ichthyology 28 (1): 140-142.

DOI: $10.1111 / \mathrm{j} .1439-0426.2011 .01875 . \mathrm{x}$
Vega-Cendejas M.E., Mexicano-Cintora G., Arce A.M. 1997. Biology of the thread herring Opisthonema oglinum (Pisces: Clupeidae) from a beach seine fishery of the Campeche Bank, Mexico. Fisheries Research 30 (1-2): 117-126. DOI: $10.1016 / \mathrm{S} 0165-7836(96) 00547-4$

Velázquez-Velázquez E., Navarro Alberto J., Domínguez Cisneros S.E., Vega-Cendejas M.E. 2009. Length-weight relationships for 24 fish species in a coastal lagoon of the Mexican south Pacific. Journal of Applied Ichthyology 25 (2): 228 229.

DOI: 10.1111/j.1439-0426.2008.01199.x

Xie J.Y., Kang Z.J., Yang J., Yang D.D. 2015. Lengthweight relationships for 15 fish species from the Hunan Hupingshan National Nature Reserve in central China. Journal of Applied Ichthyology 31 (1): 221-222. DOI: 10.1111 /jai.12465

Received: 21 April 2017 Accepted: 5 October 2017 Published electronically: 31 December 2017 